\title{
Influence of Motivation and Quality of Work Life on The Performance of Employees
}

\author{
Meithiana Indrasari ${ }^{1)}$, Mujtaba M Momin²), Nur Syamsudin3), Peter Newcombe ${ }^{4)}$, Surja \\ Permana ${ }^{5)}$ \\ 1)Dr Soetomo University Surabaya, Indonesia \\ E-mail : meithiana.indrasari@unitomo.ac.id \\ 2)American University Of The Middle East, Kuwait \\ E-mail : mujtaba.momin@aum.edu.kw
}

3) The State Islamic UniversityWalisongo Semarang, Indonesia

E-mail : nursyamsudin@walisongo.ac.id

4)University of Queensland Brisbane, Autstralia

E-mail: newc@psy.uq.edu.au

5)Borneo Christian Institute East Kalimantan, Indonesia

E-mail : dr.surjapermana@institutkristenborneo.ac.id

\begin{abstract}
This examines the influence of motivation and quality of work life on employee performance CV. Prima Indo Tuna in Makassar. This type of research is explanatory attempt to explain the factors that affect the performance of the employees of the two factors, namely the motivation and the quality of working life. Respondents were 50 people who were employees at CV. Prima Indo Tuna Makassar on the processing or production either permanent or contract employee. Analysis of hypothesis verification regression analysis, which showed no significant influence between the variables of motivation and quality of work life on employee performance, it is proved by $\mathrm{F}$ count $6,806 \mathrm{~F}$ table 3.20 . From the analysis of the partial test proved that there is a significant influence on the variables of motivation and the quality of working life to the performance. Then the partial test results obtained by the partial determination coefficient $\left(\mathrm{r}^{2}\right)$ of 0108 which shows motivation variable is the dominant variable affecting employee performance.
\end{abstract}

Keyword : Motivation, Quality of Work Life and Performance

\section{Introduction}

In addition to addressing the problem of skills and expertise, human resource management also has an obligation to build a conducive behavior of employees in relation to produce a good performance or performance. Hasibuan (2003) SDM is integrated capabilities of the intellect and physical power of the individual. HR became the first and foremost 
element in any activities conducted. Sophisticated equipment without the active role of HR does not mean anything. Meanwhile, according to Ali (2009), Human Resources is an important factor in a development process within an organization or company. The human factor is considered Life reason because human resources are not only the object, but also be the subject of the competitive existence of competition in the business world requires companies to think about how a company is able to adapt to changing circumstances. Environmental adaptation could mean in terms of the administrative environment of the company, other than that the company should be able to see the need for change if they want to maintain a workforce that has a high performance. The basic principle of employee performance is the result of a complex process, both from within the employee's personnel (internal factors) as well as the strategic efforts of the company (external factors).Internal factors such as motivation, goals, expectations, etc., while examples of external factors including physical work environment and non-physical of the company. Good employee performance certainly good for all companies and for management hiring, because the employee's performance is ultimately expected to enhance the company's overall performance.

To be able to do their job properly and in order to achieve these objectives, the need for a drive that can help in achieving that goal. Employee performance will be achieved if a person has the intention, motivation and basic values of good. Motivation is one of the factors that can encourage employees to strive to achieve a goal, Robbins (2003) defines that motivation is the willingness to issue a high level of effort toward organizational goals is conditioned by the effort's ability to meet individual needs. In Robbins and Timothy (2007) motivation is the result of interaction between individuals and situations. Of course, each individual has the motivational basis that is different.

In an effort to empower and development of employees, the management always tries to do the task and function through planning, organizing, staffing, directing and controlling external factors achieve their goals. In the duties and functions of the planning factor in the availability of infrastructure by the company aims to create a working environment and a conducive working environment, which could encourage employees to grow and develop and be creative in these companies. Quality of work life is a concept or philosophy of management in order to improve the quality of human resources has been known since the mid-seventies. In a further development, the quality of working life is a form of philosophy implemented by management in managing the organization in general and human resources in particular. There are four dimensions in the quality of working life is expected to improve the quality of human resources in participation in problem-solving, innovative reward system, improvement of working environment and labor restructuring.

In an organization of human resources, in this case, the employee is an important factor for the organization, therefore it is necessary the existence of things that can encourage employees to work hard and show a good performance. Two factors need to be assessed is the motivation and the quality of working life. If employees have a high motivation in the work it will encourage employees to get the job done well. Similarly, the factors that good quality of working life in the company will stimulate employees in completing the work well too. In the end, these two factors will affect the performance of the employees to help the company achieve goal predetermined. 


\section{RESEARCH METHOD}

Research Subjects

Understanding according to Sugiyono population (2003) is the population of generalization which consists of objects/ subjects that have certain qualities and characteristics defined by the researchers to learn and then drawn conclusions. Determination of the population in this study were all employees of CV. Prima Indo Tuna at Jalan Dr. Ir. Sutami No. 32 Makassar, South Sulawesi, which amounts to 70 employees, both permanent employees, and contract workers.

Definition of the sample according to Bungin $(2010 ; 10)$ is an object smaller studies that are part of a population. Referring to the opinion of Supranto (2001) includes a plurality of respondents research sample that is greater than the minimum requirement of 30 respondents. In this study of a total number of 70 employees, sampling 50 respondents from employees CV. Prima Indo Tuna in Makassar, which is on the production and processing, both permanent employees and contract workers.

\section{Data Collection}

In this study, data were collected through a closed questionnaire. The questionnaire is detailed questionnaire filled out by the respondents (Nasir, 2005; 203). What is meant by a closed questionnaire is the questions in the questionnaire have been provided an answer in the form of selecting answer choices so that respondents can just choose the answers according to what he felt in himself.

Hence the questions given to respondents already provided the answer, then the data used in this study using the ordinal level Likert scale. According Silalahi $(2009 ; 253)$ by category ordinal level response from the lowest level to a higher level according to the attributes in a certain sequence or order. Ordinal size shows the difference based on a tiered sequence by logical order according to the level of a category owned.

\section{Data Analysis}

Regression analysis aims to determine how much influence the independent variable on the dependent variable. Multiple linear regression analysis includes job motivation variable $(\mathrm{X} 1)$, the quality of work life $(\mathrm{X} 2)$ and employee performance $(\mathrm{Y})$. Here will be presented the results of multiple linear regression as shown in Table 5.9. Based on the results table recapitulation multiple linear regression test results, can finally arrange multiple linear regression equations in the study as follows:

a. Constant $=-2007$. This means that if the motivation and the quality of working life is assumed there is no then the performance of employees will decrease by -2007

b. Regression coefficients $(\mathrm{b} 1)=0.803$. This means that if the motivation to work better, then it will increase the performance of employees amounted to 0.803 units, assuming other variables remain. B1 value is positive, so the motivation to work better if it led to increased employee performance and vice versa.

c. The regression coefficient $(\mathrm{b} 2)=0.678$. This means that if the quality of work life better, then the performance of employees will increase by 0.678 units, assuming other variables remain. Value b2 is positive, so that if a better quality of working life of employees leads to increased performance and vice versa.

ei $=$ error (error). This error can be a nuisance in the regression analysis, for example, due to other factors beyond the two variables. 


\section{Result}

At this stage the first hypothesis will be tested using the $\mathrm{F}$ test to test the truth of simultaneous regression coefficient, test equipment used is the correlation coefficient $(R)$ and the coefficient of determination (R2). Two coefficients are the test used to determine the effect of closeness between the independent variable $(\mathrm{X})$ and a dependent variable $(\mathrm{Y})$. For the purposes of this test to see whether the values of the coefficient obtained real value or not between $\mathrm{F}$ calculated at a confidence level of $5 \%$ or $(0.05)$.

This can be explained by the amount of F 6.806>3.20 Ftabel the real level $\alpha=0.05 \mathrm{df}$ (2.47) and gained a significance level of 0.003 was $<0.05$. This is in accordance with the criteria established, namely if $\mathrm{F}$ count $>\mathrm{F}$ table or significance $<0.005$, then $\mathrm{Ho}$ is rejected and $\mathrm{Ha}$ accepted. This means that independent variables simultaneously have a significant influence on the dependent variable in the error rate $\geq=0.05$.

Based on the explanation of the simultaneous influence between variables independent variable $(\mathrm{X})$ on the dependent variable $(\mathrm{Y})$, where the $\mathrm{F}$ count $>\mathrm{F}$ table, it can be said to be the first hypothesis set out in this study can be accepted.

Based on the calculations in Table recapitulation of multiple linear regression testing can be concluded that:1. The results of a partial analysis, motivation $(X 1)$ to variable employee performance $(\mathrm{Y})$ obtained $\mathrm{t}$ calculate 2,385 $>\mathrm{t}$ table 2,012 to Sign. $=0.021<0.05$, Ha accepted, meaning that there is significant influence between the variables of motivation (X1) to variable employee performance $(Y)$. Based on the value of the beta coefficient $(\beta)$, the by of a positive, ie 0.317 , meaning that the increase of work motivation (X1), it will also increase the employee performance variable $(\mathrm{Y})$.

The results of a partial analysis, quality of work life $(\mathrm{X} 2)$ on employee performance variable $(\mathrm{Y})$ obtained $\mathrm{t}$ calculate 2,091 $>\mathrm{t}$ table 2,012 to Sign. $=0.042<0.05$, Ha accepted, meaning that there is significant influence between the variables of quality of work life (X2) on employee performance variable $(Y)$. Based on the value of the beta coefficient $(\beta)$ obtained positive coefficient is 0.278 means increasing the variable quality of work life (X2) will also increase the employee performance variable $(\mathrm{Y})$. Based on the explanation of the influence of individuals of each value of the independent variable $(\mathrm{X})$ on the dependent variable $(\mathrm{Y})$, where each value (Sign. T) on work motivation (X1) and the quality of working life (X2) showed the $<0.05$, it can be said that the hypothesis set out in this study can be accepted.

At this stage will be the third hypothesis testing, using this partial determination coefficient $\left(\mathrm{r}^{2}\right)$ is useful to know the extent of the contribution of the independent variable on the dependent variable. The magnitude of the effect of each independent variable on the dependent variable can be determined by looking at the value of $\mathrm{r}^{2}$ each variable presented in the following table:

Table 1 Coefficient of Determination of Partial

\begin{tabular}{|c|c|c|c|c|}
\hline \multirow{2}{*}{ Variable } & \multirow{2}{*}{$\mathbf{t}$} & \multirow{2}{*}{ Sig. } & \multicolumn{2}{|c|}{ Correlations } \\
\hline & & & $\mathbf{r}$ & $\mathbf{r}^{2}$ \\
\hline Motivation (X1) & 2.385 & 0.021 & 0329 & 0.108 \\
\hline Quality of Work Life (X2) & 2,091 & 0.042 & 0.292 & 0.085 \\
\hline
\end{tabular}

From the table, it can be seen the value $\mathrm{r} 2$ motivation variable (X1) is 0.108 means that the effect of motivation variables on the performance of employees amounted to $10,8 \%$. This is because the value of the variable $\mathrm{r} 2$ greatest motivation of the variable quality of working life, which means that work motivation (X1) the dominant influence on the performance of employees is $10.8 \%$. Thus the third hypothesis in this study is acceptable. 


\section{Discussion}

One of the important factors that could encourage the employee performance improvement is the motivation to work. Peneliltian The results indicate that employee motivation CV. Prima Indo Tuna Makassar is high, it is supported by the results of studies showing that the salary received by the employee can meet the needs of family life is decent, benefits of companies can improve employee morale to work, the company provides the opportunity for karyawa, employees feel to add ability and skills by taking training, the company gives the employee an opportunity to improve the status or position toward better conditions of employment may provide a sense of security and comfort during work, the company providing the means and procedures for a good work space so that employees' can work comfortably, colleagues working to provide support and assistance when employees there who are having trouble.

These results indicate that the quality of working life of employees in the CV. Prima Indo Tuna Makassar is good, it is supported by the results of studies showing that the employer directly or indirectly involve employees in defining something related to work, bosses give employees an opportunity to submit suggestions/opinions to solve a problem with work, employees are given opportunity by the company to develop themselves through training to improve skills and knowledge, employees are given the opportunity to use the means or the expertise to get the job done so much faster, employees feel protected by job security within the enterprise, employees are supported with facilities safe working at the time work, employers provide time to receive complaints or problems that employees face, the employee is satisfied with the settlement of the problem or conflict conducted by the company, the company has provided a fair salary in accordance with the work performed by employees, system of rewards and sanctions provided by the company is in compliance.

Thus both factors in this study are the motivation and the quality of working life is a component of satisfaction that wants to be perceived by employees, especially in the CV. Prima Indo Tuna Makassar to support the achievement of the performance of employees. An employee will have a good employee performance, if it has desires, hopes, needs, objectives, goals, encouragement, and incentives are supported by a good quality of working life. So as to motivate and improve the quality of working life of employees, it can improve employee performance in CV. Prima Indo Tuna Makassar able to achieve the objectives set and still exist in the era of intense competition at this time.

\section{CONCLUSION AND SUGGESTION \\ Conclusion}

Based on the problems and discussion about the influence of motivation and quality of work life employee to employee performance in CV. Prima Indo Tuna in Makassar, it can be concluded as follows:

a. Based on t-test results, it can be seen that the independent variables consist of motivation (X1) and the quality of working life (X2) partially significant effect on the dependent variable, namely the performance of employees ( $Y$ ). This is evidenced by the $t$ value of each independent variable bigger than $t$ table.

b. F test results, it can be seen that the independent variables consist of motivation (X1) and the quality of working life (X2) simultaneously significant effect on the dependent variable is employee performance $(\mathrm{Y})$. This is evidenced by $\mathrm{F}$ count larger than $\mathrm{F}$ table. 
c. Based on the results of multiple regression analysis, it can be seen that the motivation variable $(\mathrm{X} 1)$ is the independent variable the dominant influence on the dependent variable $(\mathrm{Y})$. This is indicated by the partial determination coefficient $(\mathrm{r} 2)$, where work motivation (X1) has a partial determination coefficient ( $\mathrm{r} 2)$ is the highest compared with the variable quality of work life (X2).

\section{Suggestion}

Based on the research, some suggestions for future research as well as to the management of CV. Prima Indo Tuna Makassar. The results showed that the variables of motivation have a significant influence and the most dominant influence on employee performance, it is recommended that the management of CV. Indo Prima Makassar Tuna should be able to give attention and motivation to its employees as follows:

a. Results of research on the motivation variable items workplace conditions and the provision of facilities and spatial good work, assessment of respondents were in the category enough. This needs the attention of the management to be able to create and provide a good workplace that gives security and comfort during work so as to encourage the motivation of employees to be high in the work.

b. In the above item motivation variable in performance to be achieved and the recognition and appreciation of outstanding employees, the assessment of respondents were in the category enough. objects/subjects can be enhanced by management with more appreciation and respect for employees are encouraged considered a proven record of spurring motivation of employees to work better.

c. In the item on the involvement of employees in the variable quality of working life, respondents were also still assessing the category enough, it is suggested should be the boss more intensive interaction and communication to employees and between employees and the employer, so as to create an atmosphere of togetherness and make it easier to resolve the constraints that exist,

To optimize the results of this study, it is expected that further research on the same issue could add other variables considered relevant and more profound discussion, such commitments or for job satisfaction or to distinguish the level of productivity of employees at each section or unit of work. Besides, the questionnaire should wear in the filling and interviews guided directly to each employee under investigation, so that the questionnaire will be filled with good.

\section{Reference}

Arifin, Noor. 1999. "Concept Application Quality of work life in Effort to Grow Motivation Employee Performance Excellence of control Businessman. No. 10, p 25-29.

Basaria Lumbanraja, 2012, "Pengaruh Gaya Kepemimpinan Dan Motivasi Kerja Terhadap Kinerja Guru Di SMP Negeri 1 Pandan", Universitas Terbuka Jakarta.

Budiman, Juju Juhaeriah dan E. Eryana Dinata, 2009, "Analisis Faktor Dominan Motivasi Kerja Perawat Di Instalasi Rawat Inap Rumah Sakit Umum Bayu Asih Purwakarta", Stikes A. Yani Cimahi.

Cascio, Wayne F. 2012. Managing Human Resources: Productivity, Quality of Work Life, Profits. Spektra, Jakarta.

George, Claud S, 1999, Organisasi dan Motivasi: Dasar Peningkatan Produktivitas. Jakarta, 1999. 
Hasibuan, H Malayu. 2003. Manajemen Sumberdaya Manusia. Revised Edition. Jakarta: PT Bumi Aksara.

Husnawati, A. 2006, Analisis Pengaruh Kualitas Kehidupan Kerja Terhadap Kinerja Karyawan Dengan Komitmen Dan Kepuasan Kerja Sebagai Intervening Variabel (Studi Pada Perum Pegadaian Kanwil VI Semarang). Tesis. Magister Manajemen Universitas Diponegoro, Semarang.

Iwan Soeroto, 2014, "Pengaruh Kualitas Kehidupan Kerja Terhadap Kinerja Pegawai Pada PT TASPEN (PERSERO) Kantor Cabang Utama Surabaya", Universitas Dr. Sutomo, Surabaya.

Mangkunegara, AA Anwar Prabu, Evaluasi Kinerja Sumber Daya Manusia, Bandung: Defika Aditama, 2006.

Mangkunegara. Anwar Prabu AA, 2007, Evaluasi Kinerja SDM. Refika Aditama. Bandung. Maslow, Abraham H. 1994. Motivasi dan Kepribadian 1 (Teori Motivasi dengan Pendekatan Hierarki Kebutuhan Manusia). Jakarta: PT. PBP.

Nasir, 2005, Metode Penelitian. Bogor Selatan: Ghalia Indonesia.

Nawawi, Hadari, 2005, Manajemen Sumber Daya Manusia Untuk Bisnis Yang Kompetitif, Gadjah Mada University Press, Yogyakarta.

Pruijt, Hans, 2003, "Performance and Quality of Work Life reason for effort Journal of Organizational Change Management, Vol. 13, p.389-400.

Robbin, Stephen P dan Timothy A. Judge, 2006, Perilaku Organisasi, Prentice Hall, Jakarta. Sedarmayanti. 2001, Sumber Daya Manusia dan Produktivitas Kerja, Mandar Maju, Bandung. Sedarmayanti. 2014. Manajemen Sumber Daya Manusia, Reformasi Birokrasi dan Manajemen Pegawai Negeri Sipil. Bandung: Refika Aditama.

Sugiyono. 2010. Metode Penelitian Kuantitatif Kualitatif dan R\&D. Bandung: Alfabeta.

Zin, Razali Mat, 2004, “ Perception of Professional Engineers Toward Quality of Work Life and Organizational Commitment", Gajahmada International Journal of Business, Vol. 6. No. 3, p.323-334. 